\title{
The impact of the Mobile Legend game in creating virtual reality
}

\author{
Khefti Al Mawalia \\ Pusat Informasi dan Humas, Universitas Airlangga, Surabaya \\ Address: Jalan Dr. Ir. H. Soekarno, Surabaya 60115 \\ E-mail: khefti95@gmail.com
}

\begin{abstract}
Online games have been very popular nowadays, more than games played by children and teenagers 30 years ago. This study aims to explore technological developments that people are interested in, namely the phenomenon of the emergence of the online game Mobile Legend. Mobile Legend has succeeded in making Indonesians interested because of its avatar, message feature, and buying and selling of online characters in one application. The evolution of online games from PC to Smartphone makes it easier for gamers to play games anywhere and anytime. Not infrequently, they can spend up to 6 hours a day looking for internet network access. Researchers use determinism theory to answer this phenomenon. The method in this study uses a qualitative type with a virtual ethnographic method. In addition, this research collects data on using virtual tracing to record and documenting virtual activities, and interviews with seven informants of Mobile Legends' players. This research shows that when a person plays games, he can become more apathetic and minimize interaction and communication with the social environment around him. Technology like Mobile Legend has eroded the sociocultural side and communication sensitivity of an individual in society. All users also become more active and narcissistic in creating multiple identities that exist in the virtual world. So this research shows that online games in creating virtual reality have both positive and negative impacts on the players.
\end{abstract}

Keywords: online games, Mobile Legend, virtual, technology, virtual ethnography

\section{Introduction}

In the development of digital technology, especially the development of new media, there is simultaneous communication technology exposure. The emergence of the internet makes it easy for modern society so that their life activities depend on the internet network. The existence of the internet can easily make people communicate online. The community does not only communicate and interact with people in the regions. However, it can also reach communications from provincial to international levels. The availability of new media allows users to select information, control information, and interact with virtual reality activities. According to Flew (2002), new media will allow users to use unlimited space, expand communication networks, and show an identity different from the real world.

People can do all their activities and needs with one hand. Various kinds of applications and content are available in internet technology; one of the application features currently attracting much public attention is online games. This game is a means of entertainment for people who are no less famous than social media. Fans of online games are also not familiar with age limits, from children to adults. This online game has a large market share in Indonesia due to the large number of internet cafes (warnet) and coffee shops that provide internet network access for visitors. Usually, coffee shops also provide internet facilities for up to 24 hours. One can play online games with people around him or his virtual world friends.

The evolution of online games from PC to Smartphone makes it easier for gamers to play games anywhere and anytime. Not infrequently, they can spend up to 6 hours a day looking for internet network access. Based on statistical data from Google Analytics for 2012-2013, Indonesia's online game users increase every year. That is, $80 \%$ of online game users in Indonesia are teenagers aged 15 to 25 years. Some of them came from Jakarta, Depok, Yogyakarta, Surabaya, and Medan. Online game 


\section{Mawalia: The impact of the Mobile Legend game in creating virtual reality}

Mobile Legends: Bang-Bang is a game developer from Moonton and released on Android in China, Indonesia, Malaysia on July 11, 2016, and iOS, released on November 9, 2016.

The design of The Mobile Legend genre is for Smartphone users with the addition of a virtual pad on how to play Mobile Legend, which involves two teams attacking each other in destroying and defending bases. This game has three lines, namely top, middle, and bottom. A team of five players has one hero to play with, then has a small army that helps attack enemies and henchmen.

The Mobile Legend game is one type of online game that has many enthusiasts. This game tries to introduce a MOBA base (massive online battle arena) with two types of genres, namely Real-Time Strategy (RTS) and Role Playing Game (RPG), where the player plays the opposite character and aims to destroy the opponent. Each hero character in this game has a different role and must work together to win the match.

This game has more varied and unique heroes, like the hero Fanny who adopted one of the famous anime characters. This game limits players to only ten players, with five players per team. Each player can only choose one hero from several hero options. In other words, players cannot play all heroes. The length of the game is about ten minutes in one round. There are three main lines on the map, namely the middle, top, and bottom lines. Each lane has a turret guard, which will attack enemy units automatically. Each lane also has a "barrack" building, which will make the opponent's creep or minion stronger if the opponent manages to destroy the barracks. If the opponent manages to destroy all the 'barracks,' the opposing team will have a super minion that is much stronger than ordinary minions. The game ends when a team succeeds in destroying the enemy's base. Due to the ease of installation on a cell phone, a player can play it anytime and anywhere.

The existence of chat and telephone or voice features between users shows users' social identity with the social networking site's anonymity. These facilities cause a loss of self-awareness between individuals to identify and strengthen individuals in a group. Online MOBA games can make users addicted, show gadget-mediated communication as an escape medium from bad interpersonal relationships and emotional management, and be more interested in making virtual friends fill spare time. Researchers assume that excessive use of online games will lead to aggressive users. They can be an escape medium from bad interpersonal relationships and emotional management, and can be more interested in making virtual friends fill spare time. Researchers assume that excessive use of online games will lead to aggressive users.

\section{Methods}

This study chooses a qualitative type using the virtual ethnographic method. A method has become a trend lately because it uses data collection through real fields and virtual fields (Achmad \& Ida 2018; Hine 2000). This method is very suitable for this research because it acts as a participant-observer to get direct and original information from research subjects (Achmad 2019; Achmad \& Ida 2019; Angelone 2018). The advantage of this method is that it provides intermittent time flexibility for researchers to engage in the lives and activities of subjects and informants so that it does not involve researchers full time as a traditional ethnographic study (Achmad, Ida, \& Mustain 2020; Achmad, Juwito, \& Saud 2020; Hine 2004; Hine 2015). Data collection technique uses virtual tracing to record and documenting virtual activities. Also, conducts face-to-face and online interviews with seven informants of Mobile Legends' players. 
Table 1

List of Legend Players Informants

\begin{tabular}{ccccc}
\hline Name & Age & Gender & Hour/day & Rank \\
\hline APU & 19 years & Female & $6-10$ hours & Elite \\
NN & 23 years & Female & $6-8$ hours & Legend \\
SP & 20 years & Male & $3-5$ hours & Legend \\
AK & 24 years & Male & $2-4$ hours & Legend \\
APR & 24 years & Male & $3-5$ hours & Mythic \\
ASK & 26 years & Male & $5-10$ hours & Mythic \\
SH & 24 years & Female & $3-5$ hours & Legend \\
\hline
\end{tabular}

\section{Results and Discussion}

In the beginning, humans created technology to make work and communication easier. However, over time, technological developments often make humans act out of control. Without realizing it, technology influences humans who create it themselves. This is a foundation of theoretical determinism. Marshall McLuhan first introduced the theory of determinism in 1962 in his writing entitled "The Making of Typographic Man." This paper's idea is that changes that occur in various kinds of communication will shape the patterns of interaction and existence itself. Determinism comes from the word determine, which means the influence to decide or determine something or technological determinism is a technology that affects or determines human behavior. Technology shapes the way individuals think, behave in society, and eventually direct humans to move from one technological century to another (Nurudin 2011: 184).

Several stages can shape human life. First, the discovery of communication technology led to cultural changes. Second, changes in the types of communication shape human life. Third, when humans create a communication technology tool, it indirectly shape and influence human life. Media is nothing but a tool to strengthen, strengthen, and expand human feelings' function - the discovery of new media. According to Smith in Saefullah (2007: 28), the theory of technological determinism begins with the assumption that technology is a force in regulating society. This view implies that society's social structure is considered a condition and situation formed by materialistic technology. When associated with the use of application technology in smartphones, humans use this application to facilitate all their needs and human entertainment itself. For example, in the convergence era, in one smartphone, humans can do everything in one hand. There are various kinds of features in one application, including providing messages, telephone, gaming, and can shape human behavior itself. The more often people use technology, the more people cannot let go of dependence on it.

Technology has become a very influential part of social life. Daniel Chandler, in Thurlow et al. (2004: 41), mentions some fundamental assumptions concerning technological determinism, namely, firstly reductionism. Technology determinism becomes a barrier that gives the distance between technology and culture so that the existence of technology will gradually eliminate some cultural values that have been in the midst of society. Even the existence of this technology also destroys the cultural values that have embedded. Then the second is monistic. Determinism technology becomes a simplifying factor from a complex system that becomes easier. The third assumption is neutralizing. The nature of this technology is neutral. The existence of good and bad effects depends on the technology users themselves. We often know that technology users perceive technology as a source of error or crime too quickly, even though the impact comes from the technology users themselves. Fourth, imperative technological, namely technology, which has several basic properties, including technological 


\section{Mawalia: The impact of the Mobile Legend game in creating virtual reality}

development, can never be stopped. Its existence always follows the development of the developing cultural era.

Proponents of technological determinism believe that technology is, directly and indirectly, the prime mover of social change. Supporters can be categorized into two primary schools, namely optimists and pessimists. Both believe that technology can change society.

\footnotetext{
"This view has its modernm origins in Baconian conception of knowledge as power, in the social philosophies such ninteenth century thinkers as Saint Simon and August Comte". Meanwhile, according to the second stream (pessimism), namely, "Is heir to two different traditions. It is akin to historical back to nature attitudes toward the world, such as we associate with Jean Jacques Rousseau and Henry horeau. It also derives from traditional socialist citiques of the appropriation of technology as capital." Masthene (1970: 16).
}

McLuhan's most famous phrase is medium is the message. According to McLuhan, the media used to convey messages is not only a tool but also has a specific role. The decision to choose a particular media will have an impact. In addition to human dependence on technology, humans can also create their virtual world. He can make his second world life in cyberspace. It can occur because of interactions between social media users or other games, the creation of virtual identities and changes in behavior in the virtual world and the real world, and the virtual world's space to do everything in one application at once.

Roger Fidler introduces the term "mediamorphosis," which discusses technology's evolution in communication media (Fidler 1997). Mediamorphosis is defined as the transformation of communication media that is focused on technological developments. New media can be understood not only as new media appearing in communication media. The media emerged from old media innovations that were no longer relevant to current technological developments (Achmad 2020b).

One part of the new media is the "Network Society". "Network Society" is a social formation that infrastructure from groups, organizations, and mass communities confirms the initial form of the organization from all aspects (individuals, groups, organizations, and social groups). In other words, the fundamental aspects of the formation of this theory are those that have broad collectivist relationships (Achmad 2020a; Van Dijk 2012).

Virtual reality systems project users into cyberspace by creating the illusion of being in a threedimensional database. Humans themselves can control the forms of cyber media, space, time, and reality. According to Fidler (2003: 283), humans have spent two centuries to make vehicles that keep getting faster and more efficient in traveling to faraway places. Virtual reality has moved the real world to the virtual world very quickly.

Boelstorf describes the difference between the virtual world and the real world in which we live. Virtual comes from Latin, namely Virtus, which refers to masculinity and etymologically, namely virtue, skill, and masculinity. This idea is drawn from the classical oppositions of mind and body, object and essence, and institution structure. However, in contemporary English, the virtual meaning becomes the word "almost," that is when people say "she is virtually my sister" (Levy 2001: 56) so that virtual has a close connotation without having to be present or come in one place (real world).

The real and virtual world gap is significant because there would not be a virtual world without the real world before. Until finally, binarism between nature and culture and the boundaries are online and offline (Boellstorf 2008: 18-19). Even though virtual is as natural as actual, actual world reality cannot explain the virtual world's reality. Events and virtual world identities come from real-world references (race, gender, and others). Understanding the virtual world to understand the term does not mean ignoring human existence in the real world. Exploring these relationships does not mean that every 
research project about the virtual world must have a real-world component. The history of the development of virtual reality is described as follows:

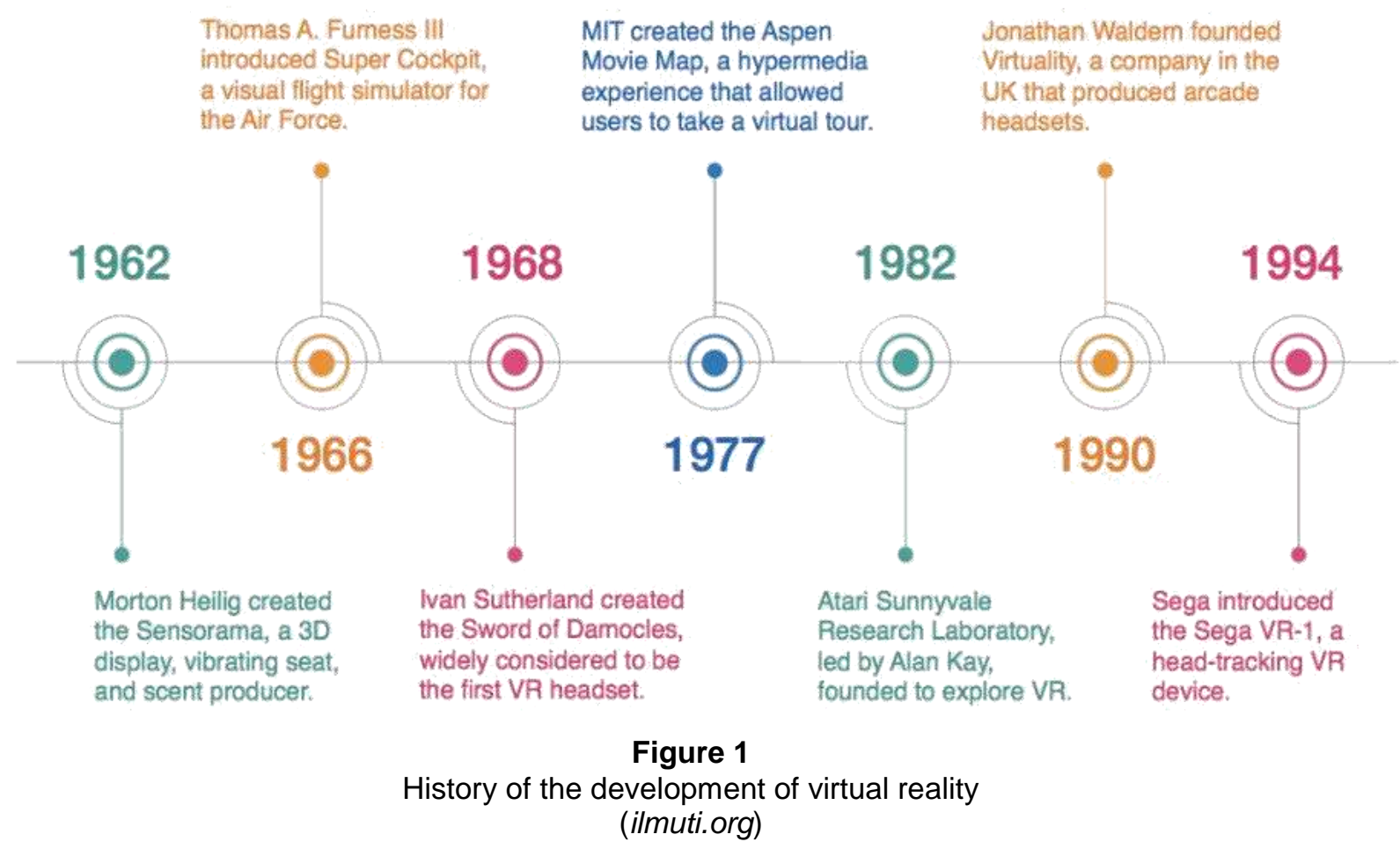

In connection with the progress of the times, technological developments are now becoming increasingly rapid. The playing space and interaction among game users have also changed, and the variety of games is also growing. One of the most popular games among young people to adults is online games. An online game is a game that can be operated using the internet network.

Young (2005) states that online games are networked games, where interaction between one person and another aims to achieve goals, vision, and mission to achieve the highest value in the virtual world. This game can be played by many people simultaneously in one hand. This game is more accurately described as a technology than as a genre or type of game. The mechanism of the game is for connecting players to one another.

According to Hall in Jan \& Kowert (2015), it is explained that identification in certain social groups such as gamers is a definition of individuals based on the division of identity applied from the outside. Social identity serves to describe itself socially concerning other people and contributes to feelings of belonging and self-worth. The social identity model of de-individuation effects (SIDE), according to Lea, Spears in Vilanova (2016), explains that this model will test anonymity and anonymity to change the meaning of personal identity and social identity. So it can have a profound effect on behavior. The anonymity comes from social networking sites and CMC, which leads to the loss of consciousness of the individual. It can identify and strengthen individual and group identities (Ramadani 2018).

The existence of virtual reality in online games certainly raises the concept of virtual identity. The virtual world offers a different form that is flexible, freer, not decentralized, always in the process (Turkle 2005). Players in the game will automatically be free to enter and exit the group of play. It interacts with a wide variety of people, and its characteristics assure a wide variety of roles. A player is also free to choose his gender. In addition, Turkle (2005) also describes that if the player is a dog in a 


\section{Mawalia: The impact of the Mobile Legend game in creating virtual reality}

virtual world, no one will know who the player's real identity is. Identity in cyberspace never has boundaries. We may never physically know whom we are connected to in the online world. The existence of thousands of players in the virtual world allows the formation of new identities, fake identities, and multiple identities that are in it. That is what will make identity addictive, as expressed by Tychen.

Specific character designs in the virtual world will open up all kinds of opportunities to construct their own identities without the need to fear punishment or hatred in the community (Tychen, Tosca, \& Brolund 2006). Fiction, fact, reality, and virtual that are full of engineering and simulation, so that it seems as if it becomes real at the same time it will mix the past, present, and future in an artificial context. This artificial reality may be known, which is a false reality and artificial reality - all in one, namely popular culture. By depicting users as living avatars, the virtual reality system provides two distinct characteristics, namely the voice and the internet network. The depiction will still create an opportunity for the user to remain anonymous. The user can either take his part in any fantasy they desire, from a samurai warrior to an alien species, or take on a charm or appearance similar to the original user's character and image.

These users need not be embarrassed by their appearance in cyberspace, so interaction and engagement can occur without hesitation. According to Fidler (2003: 286), more powerful microscopes hope to provide the potential needed to provide tactile movements and feelings that feel alive and virtual environments that are much more realistic in the coming decades. With an avatar, different types of communication can automatically become more efficient, persona, and natural. The existence of this virtual reality allows users to form a dual identity between real and virtual. A person has freedom of expression and shows their behavior without pressure from others.

The results of this discussion indicate that there is a high intensity of play among game users, which allows addiction to playing. The intensity of playing games that are too high can have a negative and detrimental impact. Seven informants in this study had the intensity of playing for approximately 3-10 hours a day with the rank of Elite - Mythic. Based on the identities in table 1, the addiction of the players in playing Mobile Legend is shown at a very high intensity of play. Not only playing games, but there are also several features available, namely, chat, voice or voice, purchasing character skins, creating groups for teams, downloading profiles, and more. This feature can provide facilities for players to interact or send messages and talk directly with their co-stars through voice.

When players use the Mobile Legend game application, technology can also influence the player's behavior or way of thinking. Moreover, the Mobile Legend game is not only limited to playing ordinary games, but this game has a chat or voice feature so that players can interact and communicate. That communication can lead to virtual communication that allows friendship and friendship in cyberspace to form a community.

This game has a very diverse and varied impact, namely if a player in the real world is a quiet figure playing in this game, then in the virtual world, he can express himself very attractively. That is in line with explaining an informant named AK, a 24-year-old male figure. AK's passive and quiet nature in the real world can finally express himself through the virtual world or virtual. It was as if he had found a place to vent the solitude he had felt so far.

\footnotetext{
"Selama ini saya merupakan orang yang pendiam saat berkumpul dengan teman sebaya atau lingkngan tempat saya tinggal. Namun setelah saya mengenal game ini, saya merasa mempunyai wadah dan teman bermain. Sehingga saya dapat melakukan segala sesuatu yang saya sukai termasuk berinteraksi dengan dunia maya." (Wawancara dengan AK).

("So far, I am a quiet person when hanging out with peers or the environment where I live. However, after I got to know this game, I felt I had a place and a friend to play. So that I can do everything I like including interacting with the virtual world." (Interview with AK)).
} 
AK's experience certainly adds new friends in the virtual world. Daniel Chandler, in Thurlow et al. (2004: 41), mentions some fundamental assumptions concerning technological determinism, namely, firstly reductionism. Technology determinism becomes a barrier that gives the distance between technology and culture so that the existence of technology will gradually eliminate some of the cultural values that have been in the midst of society. That will be bad for users because they will become more passive when meeting friends and their environment in the real world. Real-world chat is becoming a virtual world. Mobile Legend players are becoming more apathetic towards something around them. $\mathrm{He}$ forgets the presence of his social environment by being more concerned with playing games and being more interested in interacting with his virtual friends than friends beside him. The inherent sociocultural values fade as a result of culture eroded by technology in their hands. Without realizing it, technology has controlled the players themselves. Humans seem to be helpless and spend their activities to play games. In contrast to NN's opinion, a 23-year-old informant said that playing Mobile Legend can improve brain and movement performance.

\footnotetext{
"Mobile Legend dapat memebuat saya menjadi lebih bersemangat dalam melakukan segala hal. Sehingga dapat membuat saya meningkatkan strategi, membangun adrenalin dan semangat untuk menyelesaikan tugas".

("Mobile Legend can make me more enthusiastic about doing everything. So that it can make me improve strategy, build adrenaline and enthusiasm to complete tasks.")
}

The existence of a computer-mediated communication system allows for unique experiences for each individual, one of which is NN. The first time NN used this game, she admitted to using this game because it started with her boyfriend's invitation to play. When he followed that advice, he eventually became proficient with Legend rank. However, over time he met people or virtual friends using an avatar profile photo. Then they both get along well and get used to playing with the team and always win until finally he is attracted to his co-star.

\begin{abstract}
"Saya ngerasa kayak klop dengan dia tanpa saling chating. Lalu dia ngajakin saya main. Terus pas main dia nyalain fitur chat dan suara obrolan. Dan dia ngomong, aku disuruh hidupin microphone. Dan aku gak mau karena mayoritas yang ada dalam tim Mobile Legend itu cowok. Tiba-tiba saya merasa aneh dan grogi denger suaranya. Disitulah saya sadar kalo sebenarnya saya suka. Namun entah kenapa suatu hari tim kita kalah. Kemudian dia chat di grup tim dan bilang maaf karena anaknya sedang menangis. Disitulah saya merasa sakit hati". (Wawancara dengan NN).

("I feel like I fit in with him without chatting. Then he persuaded me to play. Then when he was playing, he turned on the chat and voice chat features. And he said I was told to turn on the microphone. And I don't want it because the majority in the Mobile Legend team are boys. Suddenly I felt strange and nervous, hearing his voice. That is where I realized that I really like it. But somehow, one day, our team lost. Then he chatted in the team group and said sorry because his son was crying. That's where I felt hurt." (Interview with NN)).
\end{abstract}

The interactions that occur, such as NN informants' experiences, often occur in the virtual world. When playing Mobile Legend, people try to approach the opposite sex as if they are in a mode or want to get a partner, so that someone can quickly get closer and form a chemistry. In addition to the approach, the hero characters used in the virtual world also influence that will open up various opportunities in constructing identities without the need to fear punishment or hatred in the community (Tychen, Tosca, $\&$ Brolund 2006). The avatar's role in the virtual world creates engineering and simulation, so it seems as if the avatar becomes real and will mix the past, present, and future in an artificial context. If someone plays a game, then the player will forget his identity in the real world. This reality will allow a pseudo-reality as if all data are correct or valid. Then the second is monistic. Determinism technology becomes a simplifying factor from a complex system that becomes easier. With gaming technology, it 


\title{
Mawalia: The impact of the Mobile Legend game in creating virtual reality
}

is an efficient and easy medium to find entertainment. Unlike previous centuries, today, people are looking for entertainment with a device or feature on a smartphone. The sophistication of the technology will be able to make humans immortalize the essential elements in their lives through the technology that is in front of them. Technology makes all human needs more practical.

\footnotetext{
"Bagi saya ini hanya untuk hiburan. Bermain Mobile Legend adalah untuk mengurangi stress dan meninggalkan sejenak tanggung jawab. Namun sekarang banyak diadakan kompetisi game. Sehingga bermain ini jika di tekuni tidak terlalu sia-sia." (Wawancara dengan APU)

("For me, this is just for entertainment. Playing Mobile Legend is to reduce stress and leave responsibility for a moment. But now there are many game competitions. So playing this if you try to do it is not too in vain." (Interview with APU)).
}

Third, namely neutralizing, the nature of this technology is neutral. The existence of good and bad effects depends on the technology users themselves. Humans create and develop technology, so humans should control its use in playing technology, especially in playing the Mobile Legend game. Players should be able to use the time-intensity and use of in-app features wisely so that technology users do not readily perceive technology as a source of error or crime.

Based on the study results, three female informants who played Mobile Legend revealed that the female player was more careful in playing. Especially in this game, there are more men than women. They admitted that many men uttered sarcasm or swearing so that the women did not activate their voice features and did not care about what the men in the team discussed, ass experienced by $\mathrm{SH}$ when playing Mobile Legend with his team.

\begin{abstract}
"Saat saya bermain Mobile Legend, ada cowok-cowok yang kadang mengajak kenalan, dan meminta kontak person saya. Alasannya sih untuk memperbanyak teman di dunia virtual. Tak jarang saya pernah satu tim dengan tim yang terdiri dari 3 laki-laki dan 2 perempuan. Kemudian partner perempuan saya tersebut memasang foto profil (payudaranya terlihat). Kemudian para laki-laki itu mengajak perempuan itu bermain ke semak-semak dalam dunia virtual. Namun teman perempuan saya tetap saja acuh tidak acuh dengan laki-laki tersebut”.

("When I play Mobile Legend, sometimes some guys asked me to meet people and asked for my contact. The reason is to make more friends in the virtual world. It is not uncommon for me to have a team with three men and two women. Then my female partner put up a profile photo (her breasts are visible). Then the men invite the woman to play in the bush in the virtual world. However, my female friends are still indifferent to the man.")
\end{abstract}

The statements in the interview above prove that users of this game application can maintain their safety in using technology so that users can use technology intelligently, as the name smartphone implies. Fourth, technological imperative, namely technology, which has several basic properties, namely, technological development, can never be stopped because its existence always follows the times and the developing culture. Currently, the existence of games often evolves and develops according to the times. The development of the game is an answer to the human need to be more practical. In the past, people could only enjoy games through computer media. However, now people can use smartphones to play games. People can play games anywhere and anytime without any time limit. Internet network is no longer a secondary need, but has been transformed into a primary need and becomes part of one's life activities. That is why technology can indirectly influence and control humans by losing awareness of technology itself.

Game user activity has increased over time, due to game evolution, so that people can enjoy and play anywhere and anytime, resulting in dependence on playing. This dependence will harm users, one of which is NN, who plays games on holidays. 


\begin{abstract}
"Saya merasa mengalami ketergantungan karena ketika sekali saja kita menang, maka saya akan di invite terus oleh lawan main. Dampak buruknya yaitu lupa ibadah. Kemudian saya juga sering ditegur karena saya tidak membantu orang tua di dapur. Selain itu saya juga sering lupa waktu dan tidak sholat lantaran waktunya sudah habis."

("I feel addicted because once we win, I'll continue to be invited by the opponent. The adverse impact is forgetting to worship. Then, I was often reprimanded because I'm not helping my parents in the kitchen. Besides that, I often forget the time and don't pray because the time is up.")
\end{abstract}

Another informant who experienced the same thing was ASK. When ASK plays the game, he feels more passive and reduces his interactions with the friends around him. ASK feels that she likes playing games more than talking when she meets her friends.

\footnotetext{
"Saat dirumah, saya lebih suka menghabiskan waktu dalam bermain game. Hal itu juga terjadi saat saya makan bersama teman diluar. Jadi agar teman saya tidak merasa sendiri, saya ajak saja dia untuk bermain Mobile Legend bersama. Jadi kita ketemu dan ngobrol di dunia virtual”.

("When at home, I prefer to spend time playing games. It also happens when I eat with friends outside. So that my friend does not feel alone, I invite him to play Mobile Legend together. So we meet and chat in a virtual world.")
}

The existence of a change in behavior in virtual reality indicates a change in culture and an increasingly distant interaction. Someone will be more focused on the gadgets available in front of others and ignore the people around others so that playing games can form a dual identity in the perpetrator.

A person feels that he does not have a job and experiences anxiety, allowing players to vent himself by playing online games. Communication with people in their social sphere will be increasingly limited, and they are more interested in choosing to communicate with technology than society. Someone will also be quiet and preoccupied with their gadgets. Therefore, technology has the power to change behavior patterns that exist in society. Now the culture has been eroded by increasingly rapid technological advances.

\title{
The creation of a virtual identity
}

Researchers see that after playing, gamers tended to share photos of their winning games on social media. This behavior tends to show the player's existence in admiring himself. It is as if he shows the public that he is also a hero, like an avatar in the game. According to the American Psychiatric Association (Arif 2016), the criteria for people who have a narcissistic personality are to have a great sense of self-interest with exaggerated talents. According to the informants, the purpose of the selection in using avatars is so that people can find out about the achievements of game players who also aim to get praise, as NN states below.

\footnotetext{
"Saya seringkali share foto di facebook, instagram, twitter ketika menang dan mendapatkan reward kotak box. Saya menunjukkan bahwa perempuan juga bisa dan bisa menang juga. Alasannya yaitu untuk pamer dan jagoan."

("I often share photos on Facebook, Instagram, Twitter when I win and get a reward box. I showed that women can and can win too. The reason is to show off and be good at it.")
}

Game players often share photos of their victories when playing Mobile Legend because they aim to show individuals and teams' ability to win with a high rank or level. Meanwhile, according to female informants, the importance of women sharing and capturing these photos on social media shows that 
Mawalia: The impact of the Mobile Legend game in creating virtual reality

women are also very familiar with playing the Mobile Legend game. In other words, it is not only men who play the game.

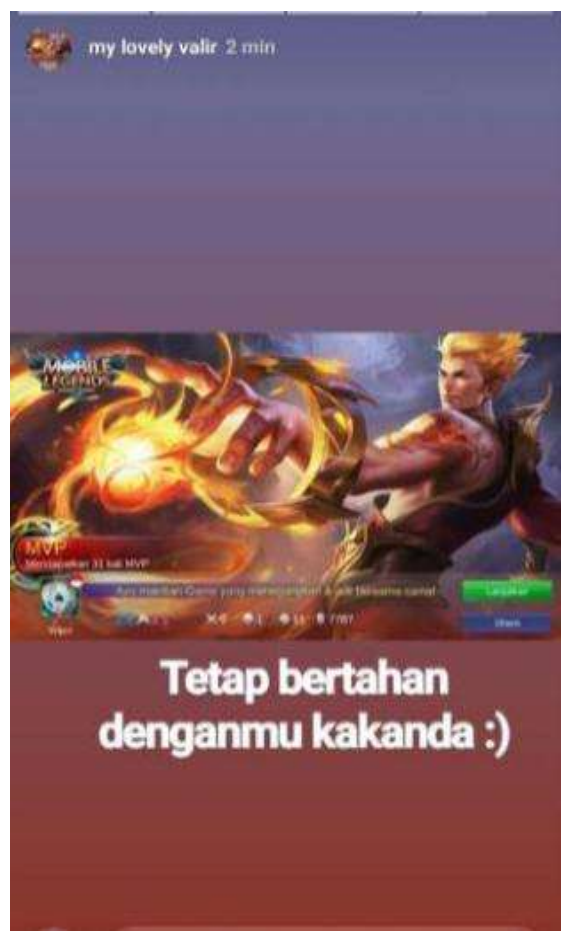

Figure 2

The victory of the female mobile legend player got $31 \mathrm{MV}$

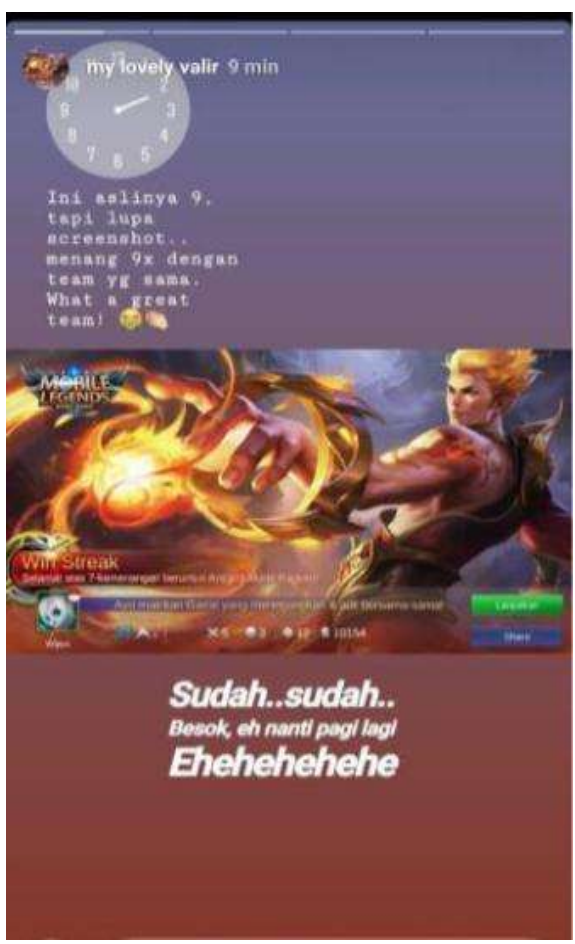

Figure 3

The victory of the female mobile legend player got 7 wins 
Even female sources also wanted to show that women are also not weak creatures and cannot play the games that men usually play. On the other hand, in playing Mobile Legend, women can also win and are also entitled to a high level of victory and rank equivalent to legend and myth. Besides, researchers found facts from informants that playing Mobile Legend requires not only the ability to play but the player's interest in the selected avatars also directly touches the player.

"Hero yang saya pilih adalah hero yang bisa mengeluarkan api. Maka hero tersebut sangat sesuai dengan karakter pribadi saya yang seringkali emosi. Sehingga di Mobile Legend saya bisa membakar apapun karena hero tersebut dapat mengeluarkan api". (Wawancara dengan NN).

("The hero I chose is a hero who can release fire, so the hero is following my personal character, who often emotional. So that in Mobile Legend, I can burn anything because the hero can make fire." (Interview with $\mathrm{NN})$ ).

This opinion is equivalent to what Banks \& Bowman said in Hart (2017), that the avatar has an attraction between the player and the avatar itself. Avatars can show the same or different identities or behaviors as players as social objects in the playroom. Players will feel they have the same life when playing the game. Players will control, for example, when buying skins in the game to make it look attractive. The transaction process of buying and selling skins in the game also allows the availability of virtual money that can spend this money to increase the hero's performance while playing and provide attractive visual effects. Not infrequently, many players spend their money to buy these skins.

\footnotetext{
"Saya menghabiskan uang 150.000 saat bermain untuk membeli skin. Hal itu bertujuan untuk meningkatkan performa dan kekuatan saat bermain dengan lawan".

("I spent 150,000 while playing to buy skins. It aims to improve performance and strength when playing against opponents.")
}

The existence of levels in the game can attract game players to increase their ranking level further. These levels consist of a warrior, elite, master, grandmaster, epic, legend, and mythic. Each level has a different difficulty level. If the players have already occupied the Mythic rank, they may also drop the level because one of the policies in this game application is to lower the level every three months. The purpose of decreasing the level is to increase the players' enthusiasm to be more challenged and not monotonous, so that not infrequently many players are willing to spend their time playing and ultimately have an impact on the occurrence of addiction in playing the game itself.

\section{Conclusion}

The rapid development of technology has resulted in the evolution of conventional games to online games. The existence of various kinds of features in Mobile Legend results in technology's influence that players consume themselves. When playing online, players' behavior tends to show achievement through social media such as WhatsApp and Instagram stories. The achievement and performance changes in the avatar give rise to a new identity in the virtual world.

The existence of higher-ranking levels and better performance will support this game. The results of interviews with informants explained that the majority of informants used online games for 3-10 hours a day, due to negative pressure or emotions from individuals that caused players to express themselves through games. Besides, players can also get acquainted with people that players have never met before. However, it will also harm the interaction process in the real world. Players will become more passive and feel dependent on the game. 


\section{Mawalia: The impact of the Mobile Legend game in creating virtual reality}

Humans will continue to follow technological developments, not the other way around. On the other hand, if society can control online games, then players will maintain their safety in playing. For example, safe from harassment of women from men virtually. Society and technology will become more balanced without favoring each other.

\section{References}

Achmad ZA \& Ida R (2018) Etnografi Virtual Sebagai Teknik Pengumpulan Data dan Metode Penelitian. The Journal of Society \& Media 2 (2): 130-145. https://doi.org/10.26740/jsm.v2n2.p130-145

Achmad ZA \& Ida R (2019) The shifting role of the listeners in the mediamorphosis process of culture radio: A case study of Jodhipati 106.1 FM. Masyarakat, Kebudayaan Dan Politik 32 (3): 240-250. https://doi.org/10.20473/mkp.v32i32019.240-250.

Achmad ZA (2019) Integrasi Program Dakwah dan Budaya: Studi Etnografi Virtual Mediamorfosis Radio Nada FM Sumenep Madura. Jurnal Komunikasi Islam 09 (2): 238-263. https://doi.org/10.15642/jki.2019.9.2.239-263.

Achmad ZA (2020a) Pergeseran Relasi Antara Pendengar Radio Dengan Institusi Radio Dalam Masyarakat Jaringan (Studi Etnografi Virtual pada Radio-radio Budaya di Jawa Timur yang Bermediamorfosis). Universitas Airlangga.

Achmad ZA (2020b) Review Buku: Mediamorphosis: Understanding New Media by Roger Fidler. Dalam: Potret Masyarakat dan Kebijakan Pemerintah dalam menghadapi tantangan Pandemi Covid-19. Editor: Nawangsari ER \& Kriswibowo A. Surabaya: Prodi Administrasi Negara UPN Veteran Jawa Timur. Hal: 71-78.

Achmad ZA, Ida R, \& Mustain M (2020) A Virtual Ethnography Study: The Role of Cultural Radios in Campursari Music Proliferation in East Java. ETNOSIA: Jurnal Etnografi Indonesia 5 (2): 221237.

Achmad ZA, Juwito J, \& Saud M (2020) The Local Creative Ads on Sritanjung Fm to Increase Financial Revenue During Covid-19 Pandemic. Bricolage: Jurnal Magister Ilmu Komunikasi 6 (2): $135-146$.

AK (2019) [Personal Communication] 25 July.

Angelone L (2018) Virtual Ethnography: The Post Possibilities of Not Being There. Mid-Western Educational Researcher 31 (3): 275-295.

APU (2019) [Personal Communication] 24 July.

Arif AF (2016) Analisis Sikap Narsisme dalam Aplikasi Instagram (Studi pada Siswa SMA Negeri 2 Bandar Lampung. Skripsi, Universitas Lampung, Lampung.

ASK (2019) [Personal Communication] 22 July.

Boellstorf T (2008) Coming of Age in Second Life: An Anthropologist Explores the Virtually Human. New Jersey: Princenton University Press.

Fidler R (1997) Mediamorphosis: Understanding New Media. Thousand Oaks: Pine Forge Press.

Fidler R (2003) Mediamorfosis. Yogyakarta: Bentang Budaya.

Flew T (2002) New Media: A Critical Introduction. United Kingdom: Oxford University Press.

Hart C (2017) Getting into the Game: An Examination of Player Personality Projection in Videogame Avatars. The International Journal of Computer Game Research 12 (2).

Hine C (2000) Virtual Ethnography. London: Sage Publications Ltd.

Hine C (2004) Virtual Ethnography Revisited. Online Reearch Methods, Research Methods Festival. Oxford.

Hine C (2015) Ethnography for the Internet: Embedded, Embodied, and Everyday. London: Bloomsbury.

Jan G \& Kowert R (2015) Going beyond the Game: development of Gamer Identities within Societal Discourse and Virtual Spaces. The Journal of the Canadian Game Studies Association 9 (14): 7087. 
Levy L (2001) The Adoring Audience: Fun Culture and Populer Media. New York \& London: Rouledge.

Masthene EG (1970) Technological Change: Its Impact on Man and Society. Cambridge, Massachusetts: Harvard University Pres.

NN (2019) [Personal Communication] 25 June \& 25 July.

Nurudin (2011) Pengantar Komunikasi Massa. Jakarta: Rajawali Pers.

Ramadani MIF (2018) Penarikan Diri dalam Game Online (Studi Deskriptif Kualitatif Withdrawal Gamer Mobile Legends Mahasiswa Ilmu Komunikasi UMS 2014). Skripsi, Universitas Muhammadiyah Surakarta, Surakarta.

Saefullah (2007) Konsep dan Metode Pelayanan Umum yang Baik dalam Jurnal Ilmu Sosial dan Ilmu Politik. Sumedang: FISIP UNPAD.

SH (2019) [Personal Communication] 24 July.

Thurlow C (2004) Computer Mediated Communication: Social Interaction and the Internet. California: SAGE Publications.

Turkle S (2005) The Second Self: Computers and teh Human Spirit. London: MIT Press.

Tychen A, Tosca S, \& Brolund T (2006) Personalizing the Player Experience in MMORPGs. Dalam: Technologies for Interactive Digital Storytelling and Entertainment. Editor: Göbel S, Malkewitz R, \& Iurgel I. Berlin: Springer.

Van Dijk JAGM (2012) The Network Society: Social Aspects of New Media (3rd ed.). London: SAGE Publications Ltd.

Young KS (2005) Internet Addiction: A handbook and guide to evaluation and treatment: Hoboken. NJ: John Wiley \& Sons. 